\title{
Integrating Students' Own Cultre in the Teaching of Vocabulary
}

\begin{abstract}
:
Many researchers make it evident that culture and language are intertwined. The present paper reports on a study about the usefulness of incorporating learners' own culture in the teaching of English as a foreign language. More specifically, it aims at investigating the impact of using elements and examples from students' cultural background to help them learn meanings of unknown vocabulary items presented to them for the first time. It is hypothesized that students are more likely to obtain and correctly guess words' meanings when these appear in a context which is familiar to them. This study takes as sample first-year LMD students at the Department of Arts and English Language, University of Constantine1. The participants take part in two tests where they have to guess the meaning of a number of vocabulary items from context. The example statements used in the first test are taken from the students' homeland culture and in the second from the host culture. The findings show that including elements from students' own culture helped them guess the meaning of new words
\end{abstract}

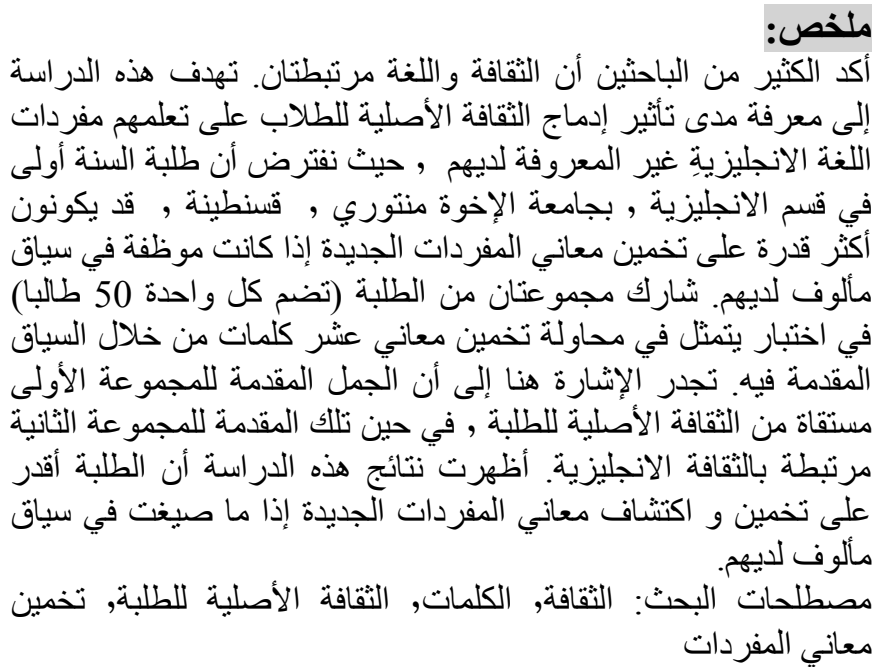

\section{CHOUAF Chahrazed}

Faculty of Letters and Languages Department of Foreign Languages

University of Mentouri Constantine

\section{Introduction:}

By way of introduction, culture and language are viewed as the two sides of the same coin by many theorists. They influence each other in many apparent ways. One such way concerns teaching languages. To be effective, the latter should entail the teaching of cultural features. At first, target language culture was incorporated into the language classroom. Later on, suggestions were made as to tap into learners' background and native culture to teach a foreign language, especially when dealing with vocabulary instruction. 
To clarify, students can learn and recall new vocabulary items better if they meet them, during initial exposure at least, in a context familiar to them. In fact, there are many countries in Latin America, Africa, and Asia where this approach is adopted in EFL teaching. Even in the United States, the Indians learn English through their indigenous culture (Barfield and Uzarski, 2009).

European countries are no exception. The Croatian national syllabus, for instance, includes elements of Croatian culture and civilisation in materials intended to teach English in the primary school (Vickov, 2007: 108).

In a similar vein, this study comes to explore the potentials of making capital from the students' homeland social and cultural specificities to teach English vocabulary in the Algerian context. This paper starts with a definition of culture before presenting different views about the relationship between language and culture. It then accounts for how this relationship influences foreign language teaching in general and vocabulary in particular. The main part of this paper, however, relates to the field work and its findings.

\section{Definition of Culture}

There may be as many definitions for the term culture as there are theorists and contexts. T. S. Eliot (1949:19) has thought of three possible meanings for 'culture'. The first is related to a person, the second to a class or group of people, and the third to a society in its entirety. He explicates that these senses are not separate but rather interconnected since an individual acquires his culture from that of a group, and the latter receives its culture from that of the whole society. Therefore, Eliot concludes, the basic meaning of culture is the one associated with society (ibid.).

Brooks (1968: 211-12) distinguishes between two different but complementary definitions of culture: formal and deep. The former denotes artistic creations pertinent to literature, drama, painting, dancing, architectural designs, politics, economics, technology and so forth. The latter refers to a community lifestyle including its values, attitudes, routines, behaviours, mores, traditions, and way of living. He advises to include such elements in curricula designed for second language (L2) instruction.

\section{Language and Culture}

During the eighteenth, well-known researchers such as Boas, Sapir, and Whorf already started investigating the relationship between language and culture (Sharifian, 2015:3). Although, a few theorists, like Boas (1940s), claimed that no connection exists between the two, most researchers -including authorities like Sapir (1920s) and his student Whorf (1930s)- believed that language and culture are intertwined (Wardhaugh, 2010: 230). This view has been supported by ample evidence later on. From 1990s onward, the issue of language-culture relationship has been the focal point of many studies in varied fields such as anthropological linguistics, sociolinguistics, cross-cultural 
communication, and translation. These studies have shown how closely culture and language relate (Risager, 2007: 1). On the one hand, they found out that socialization and developments in languages play a determinant role in shaping the world's diverse cultural identities and patterns. On the other hand, such research has demonstrated that linguistic and discourse forms articulate cultural differences, and semantic structures and pragmatic practices hold cultural conceptions and views of the world (ibid.).

According to Risager (ibid., 21-22), the language-culture connection can be explained in the light of two things:

a) the link between the linguistic practice and the cultural milieu where it takes place and

b) the link between the linguistic practice and the content or meaning it carries.

To explain, Kramsh (1998: 3-6) states that when using words, speakers/writers reveal what they think about the world and how they perceive it. Conversely, their cultural values and principles impose given benchmarks of language use and communication on them. Even more clearly, she maintains that language mirrors culture, and cultural context complements "the meaning encoded in the language".

In a nutshell, culture constitutes the means whereby language is acquired, and via the language, socio-cultural knowledge is transmitted (Buttjes, 1991:3).

Integration of Target Language Culture in the Language Classroom

Many experts have asserted that learning a language entails learning about its culture (Brooks: 1968; Kippel 1994: 50; Byram 1994: 1). Buttjes (1991: 11) reports that interest in introducing the culture in the language classroom started decades ago -during the 70's and 80's- in the USA, Britain, France, Australia, Poland, and Denmark where many international conferences were held about studies in literature and culture at university level. Early studies emphasized the inclusion of the target language culture in foreign language (FL) teaching because this:

- enlarges learners' general knowledge via becoming acquainted with the various world cultures;

- not only motivates but also facilitates students' learning of the foreign language thanks to the cultural and social context within which language is presented;

- prepares learners for contact and communication with native speakers, and thus

- leads to both interlingual and intercultural competences in ELLs (English Language Learners) (Buttjes 1991: 8-9)

In the same vein, Meyer (1991: 137) affirms that the ultimate goal of culture inclusion in language teaching is to help ELLs' develop 'intercultural 
competence', which refers to the ability to act in a flexible and adequate way when communicating with native speakers. That is, non-native speakers have to show awareness and understanding of the cultural differences existing between their own culture and the natives' so that they can solve communication problems resulting from these differences in cross-cultural situations. Building this competence is made possible because learning about other cultures help ELLs not only to comprehend 'the Other' (Kramsch, 1998: 81; Reimann, 2009: 85) but also to better understand their own culture via comparing and contrasting behaviours and beliefs in different cultures (Woods, 1994: 81). For all these reasons, Vickov (2007: 105) asserts that any FL instruction which does not include culture as a component in its curriculum is "inaccurate and incomplete."

\section{Integration of Students' own Culture in the Language Classroom}

Recently, numerous researchers have supported a shift of focus from integrating target culture to integrating ELLs' native culture in FL teaching, namely Petravić, 2004; Vickov, 2005; Tas, 2005; Tsui, 2005 (Vickov, 2007: 106). Many arguments were presented. Lynch and Hanson maintain that language learning can be affected by one's cultural background (1998 in Alhasiany, 2014: 38). Swan and Smith confirm that cultural differences may hinder ELL's learning process (2001 in Alhasiany, 2014: 39). Alptekin (1993: 137) provides a very significant explanation for the aforementioned views. He claims that learning a new language is a hard task, but it becomes harder when it occurs in a culturally-oriented fashion because learners -who belong to other cultures may have little knowledge of the host cultural systems necessary for successful interpretation of the language. In addition, teaching culture is not done objectively (Nieto 2010: 135); most EFL materials are biased (Reimann: 2009: 99) because the target culture is represented in a stereotypical way focusing on the American or British models and denying real inter-cultural perspectives in communication (Alptekin,1993: 141). For these reasons, Nieto (2010: 155) asserts that it is highly recommended to include ELLs' homeland culture in the language classroom because "students' identification with and maintenance of their native culture and language can have a positive influence on learning."

\section{Culture and vocabulary learning}

From her personal experience in EFL teaching, Thomas (2014) concludes that presenting the foreign language (English) using the foreign culture to learners coming from non English-speaking settings provides very little help for them to learn it. Alptekin (1993: 137) clarifies this situation when acknowledging that to learn a language, one needs two kinds of knowledge: systemic (a language syntax and semantics) and schematic (prior knowledge about one's society and the world in general). In the case of foreign learners, the schematic knowledge used to understand the new language is established in 
relation to the native language and culture and thus ELLs' may find themselves in a situation where differences between their own culture and the target one result either in misinterpreting or not comprehending the target language. In the same scope, Broemmel, Jordan, and Whitsett (2015: 111) state: "New vocabulary is acquired when it fits a learner's existing schema, so tapping into a student's prior knowledge is a necessary first step when introducing novel vocabulary words." That is, if vocabulary is presented to ELLs via an unfamiliar context, their linguistic and cultural backgrounds intervene and become a kind of hindrance to learning.

Many researchers agree that integrating students' first culture while teaching vocabulary should be done in a gradual fashion. For instance, Buttjes (1991: 12) suggests to utilize learners' own culture as a starting-point and then to move to other cultures. Thomas (2014: 21) proposes to present new lexical items for the first time in a context locally relevant to students; after that, transfer to other more foreign contexts can be made following the continuum below:

Familiar Content \& Language

Unfamiliar Content \& Language

\section{From Thomas (2014: 21)}

The content of a culturally-oriented lesson can be selected either by looking at society at a macro level dealing with issues such as education, government, parliamentary system, or through closely looking at how individuals behave when going out, being in family, having a meal with friends ...etc (Woods, 1994: 80; Nieto 2010: 135). According to Dong (2015: $\S 6)$, teachers should design and prepare such lessons 'with ELLs in mind'; i.e., even the examples used to introduce new concepts and words have to be chosen taking into consideration ELLs' indigenous culture and past knowledge since "[c]ulturally familiar examples give ELLs extra motivation because they become the knowledgeable ones ... it creates a rich context in which to learn academic vocabulary, because ELLs can relate new words to prior knowledge." (Dong, 2015: §7). Thomas (2014: 21) confirms this very idea when asserting that teaching materials which are 'selected with sensitivity to the local context' make the EFL learning/teaching experience lively and fruitful. With a higher degree of assertion, Dong (ibid., §11) says: "[i]t is only when ELLs are engaged in connecting new words with what they know in their native language and their prior learning that academic vocabulary learning become meaningful and effective."

\section{Research Methodology}

At the outset of this study, the following questions are posed

1- Is the inclusion of culture in EFL language teaching important?

2- Does the use of EFL students' own culture affect their learning of new words? 
3- To what extent does the use of EFL learners' cultural background influence their capacity to guess word meaning from context?

In attempt to answer them, a field work is undertaken. The subsequent sections account for this work.

\section{Participants}

In this study, the participants are randomly selected from firstyear students at the department of English at Fréres Mentouri University, Constantine, during the academic year of 2015-2016. This sample is composed of 100 subjects divided into two groups, 50 students each. First-year students are chosen because they are expected, as early as their first years of majoring in English, to acquire as much vocabulary as possible in order to cope with learning the four language skills: listening, speaking, reading and writing.

\section{Instrumentation}

To collect data, the researcher has used two different tests designed to two different groups of participants. Each test includes ten statements having one unfamiliar word apiece. The sentences in the first test are taken from Cambridge dictionary and are related to the target language culture whereas those in the second test contain elements from the students' native culture and are generated by the researcher, who was inspired by the statements in the first test. This tool of data collection (testing) is selected because it seems to be a good means for investigating the extent to which students employ their cultural background as a source for getting the right meaning of new words.

\section{Administration of the Tests}

The tests are administered to subjects in ordinary sessions by the researcher and another teacher in the department. The test takers were informed that they took part in a study and were told what they were required to do exactly. Also, they were given the necessary time to answer the question. At the end, the answers were collected for later study and analysis.

\section{Analysis of the Findings}

First of all, the outcomes of each group are discussed in isolation. Then, a comparison of both groups' results is made. Eventually, some final thoughts based on the findings of the present study are presented. 


\begin{tabular}{|l|c|c|c|c|c|c|}
\hline \multirow{2}{*}{ Items } & \multicolumn{2}{|c|}{ Right answers } & \multicolumn{2}{c|}{ Wrong } & \multicolumn{2}{c|}{ No answers } \\
\cline { 2 - 7 } & $\mathrm{N}^{\circ}$ & $\%$ & $\mathrm{~N}^{\circ}$ & $\%$ & $\mathrm{~N}^{\circ}$ & $\%$ \\
\hline accommodated & 19 & 38 & 30 & 60 & 01 & 2 \\
\hline amendment & 2 & 4 & 40 & 80 & 08 & 16 \\
\hline commodities & 31 & 62 & 15 & 30 & 05 & 10 \\
\hline consent & 38 & 76 & 11 & 22 & 01 & 2 \\
\hline fined & 33 & 66 & 17 & 34 & 00 & 0 \\
\hline fees & 45 & 90 & 05 & 10 & 00 & 0 \\
\hline index & 28 & 56 & 19 & 38 & 03 & 6 \\
\hline subsidies & 23 & 46 & 19 & 38 & 08 & 16 \\
\hline sustained & 14 & 28 & 35 & 70 & 01 & 2 \\
\hline provide...with & 41 & 82 & 07 & 14 & 02 & 4 \\
\hline
\end{tabular}

Table 1: Results of Group One

According to table 1, a great deal of subjects succeeded to infer the meaning of six words out of ten reaching percentages that are far above the average. In fact, $90 \%$ of the students correctly deduced the signification of fees, $82 \%$ got the meaning of provided...with, $76 \%$ rightly guessed the sense of consent; moreover, $66 \%, 62 \%$, and $56 \%$ of them made accurate guesses of the items fined, commodities, and index in that order. Yet, fewer students could figure out the sense of subsidies (46\%), accommodated (38\%), sustained $(28 \%)$, and amendment (4\%).

On the other hand, three words seemed to be problematic for participants because they failed to discover what they stand for; these are namely amendment (80\%), sustained (70\%), and accommodated (60\%). In addition, $16 \%$ of subjects in group one gave no guesses for the words subsidies and amendment, and $10 \%$ of them left the answer space blank for the word commodities. Only very few were those who did not respond to the items: index $(06 \%)$, provided...with $(04 \%)$, sustained, accommodated and consent (02\% each).

Likewise, the analysis of the results of group two made it possible to reach many conclusions. According to table 2 below, students' answers varied from one vocabulary item to another. For instance, many of them were able to correctly guess two words: 'consent and provide...with' as they reached the percentages of $98 \%$ and $70 \%$ respectively. However, the proportions of students who were successful in uncovering the meanings of the eight remaining words were less than half; they ranged between $46 \%$ (for index), $38 \%$ (commodities), 26\% (amendment), 24\% (fees), 18\% (subsidies /sustained), 16\% (fined), and 14\% (accommodated). 
CHOUAF Chahrazed

\begin{tabular}{|l|c|c|c|c|c|c|}
\hline \multirow{2}{*}{ Items } & \multicolumn{2}{|c|}{ Right answers } & \multicolumn{2}{c|}{ Wrong answers } & \multicolumn{2}{c|}{ No answers } \\
\cline { 2 - 7 } & $\mathrm{N}^{\circ}$ & $\%$ & $\mathrm{~N}^{\circ}$ & $\%$ & $\mathrm{~N}^{\circ}$ & $\%$ \\
\hline accommodated & 07 & 14 & 27 & 54 & 16 & 32 \\
\hline amendment & 13 & 26 & 27 & 54 & 10 & 20 \\
\hline commodities & 19 & 38 & 30 & 60 & 01 & 02 \\
\hline consent & 49 & 98 & 01 & 02 & 00 & 00 \\
\hline fined & 08 & 16 & 42 & 84 & 00 & 00 \\
\hline fees & 12 & 24 & 30 & 60 & 08 & 16 \\
\hline index & 23 & 46 & 21 & 42 & 06 & 12 \\
\hline subsidies & 09 & 18 & 38 & 76 & 03 & 06 \\
\hline sustained & 09 & 18 & 32 & 64 & 09 & 18 \\
\hline provide...with & 35 & 70 & 11 & 22 & 04 & 08 \\
\hline
\end{tabular}

Table 2: Results of Group Two

Also, some of the students seemed completely helpless with finding the sense of some words as they provided no answers at all. For instance, $32 \%$ of the participants in group two struggled with what 'accommodated' stands for; $20 \%$ with 'amendment', $18 \%$ with 'sustained', $16 \%$ with 'fees', and $12 \%$ with 'index'. Fewer of them ( $08 \%$ ) could not say what 'provided... with' means, $06 \%$ did not know how to define 'subsidies', and $02 \%$ came up with no explanation for 'commodities'.

The highest percentages, unfortunately, belong to the category of 'wrong answers'. A lot of students made incorrect guesses for seven items out of ten, and they failed to detect the correct meanings of the words: fined with a proportion of $84 \%$, subsidies ( $76 \%$ ), sustained (64\%), commodities / fees $(60 \%$ each), and amendment / accommodated (54\% each).

A combination of both groups' results, which are summed up in table 3 below, leads to a clearer picture of participants' performance.

\begin{tabular}{|l|c|c|c|c|c|c|}
\hline \multirow{2}{*}{ Items } & \multicolumn{3}{|c|}{ Group One } & \multicolumn{3}{c|}{ Group Two } \\
\cline { 2 - 7 } & $\begin{array}{c}\% \text { of } \\
\text { right } \\
\text { answers }\end{array}$ & $\begin{array}{c}\text { \% of } \\
\text { wrong } \\
\text { answers }\end{array}$ & $\begin{array}{c}\text { \% of no } \\
\text { answers }\end{array}$ & $\begin{array}{c}\% \text { of } \\
\text { right } \\
\text { answers }\end{array}$ & $\begin{array}{c}\% \text { of } \\
\text { wrong } \\
\text { answers }\end{array}$ & $\begin{array}{c}\% \text { of no } \\
\text { answers }\end{array}$ \\
\hline accommodated & 38 & 60 & 02 & 14 & 54 & 32 \\
\hline amendment & 4 & 80 & 16 & 26 & 54 & 20 \\
\hline commodities & 62 & 30 & 10 & 38 & 60 & 02 \\
\hline consent & 76 & 22 & 02 & 98 & 02 & 00 \\
\hline fined & 66 & 34 & 00 & 16 & 84 & 00 \\
\hline fees & 90 & 10 & 00 & 24 & 60 & 16 \\
\hline index & 56 & 38 & 06 & 46 & 42 & 12 \\
\hline subsidies & 46 & 38 & 16 & 18 & 76 & 06 \\
\hline sustained & 28 & 70 & 02 & 18 & 64 & 18 \\
\hline provide...with & 82 & 14 & 04 & 70 & 22 & 08 \\
\hline
\end{tabular}




\begin{tabular}{|l|c|c|c|c|c|c|}
\hline Mean & 54.8 & 39.6 & 05.8 & 36.8 & 51.2 & 11.4 \\
\hline
\end{tabular}

Table 3: Comparison of both Groups' Results

Table 3 includes a global view of the results. Accordingly, the mean of the correctly guessed words by group one was $54.8 \%$ against $36.8 \%$ for group two. In other words, those participants who dealt with the vocabulary items in a context that is familiar to them outperformed those who met the same words in an unfamiliar context. Therefore, one can deduce that the more the context contains known elements and culturally relevant information to learners the more successfully they can work out the sense of a new word, and vice versa. In fact, $51.2 \%$ of the answers provided by the participants in group two were wrong compared to only $39.6 \%$ of incorrect replies in group one. Furthermore, the percentage of the participants of group two who left some questions blank with no answers $(11.4 \%)$ doubled that of their counterparts in group one (05.8\%).

Appendices 3 and 4 give more details about the results. They show that ten participants in group one scored seven out of ten while only one participant in group two did. Thirdly, four participants of group two got the mark six out of ten, but their counterparts were fifteen in group one. In addition, there were sixteen participants of group two who committed five mistakes whereas only eight (half this number) made the same number of mistakes in group one. Hence, one may deduce that in terms of the quality of students' answers, those who were in group one outdid those in group two by providing more right answers and less wrong ones.

\section{Calculating the Means}

To be more precise and concise, central tendency and dispersion of scores are computed so that the image of the participants' overall behaviours gets statistically more obvious. Central tendency is displayed in its indicators: the mean (or the average is the result of dividing the sum of all scores by the number of participants), the mode (the mark with maximum frequency) in addition to the median (or medium is the middle point of scores above and below which there are half of the scores). Dispersion is shown in the lowest and highest scores with their respective frequencies (Fr.). After these calculations, the results are displayed in table 4:

\begin{tabular}{|l|c|c|c|c|c|c|c|}
\cline { 2 - 8 } \multicolumn{1}{c|}{} & \multicolumn{3}{c|}{ Central Tendency } & \multicolumn{4}{c|}{ Dispersion } \\
\cline { 2 - 8 } & Mode & Mean & Median & Low & Fr. & High & Fr. \\
\hline $\begin{array}{l}\text { Group } \\
\text { One }\end{array}$ & 6 & 5.64 & 6 & 2 & 2 & 9 & 1 \\
\hline
\end{tabular}




\begin{tabular}{|l|l|l|l|l|l|l|l|}
\hline $\begin{array}{l}\text { Group } \\
\text { Two }\end{array}$ & 4 & 4.18 & 4 & 1 & 2 & 8 & 1 \\
\hline
\end{tabular}

Table 4: Participants' Overall Behaviours during the Tests

Glancing at table 4 , one can notice the differences between the indicators of the central tendency of the two groups. The mean (05.64) of group one, where native culture elements are used in the test, is higher than that of group two (04.18) whose test statements evolve around foreign culture aspects. Likewise, the mode shows that the most frequent score is 06 in group one, but it drops to 04 in group two. Exactly in the same way, the median or medium grade is 06 in the first group and 04 in the second one.

The dispersion indicators, also, confirm that participants in group one performed better than those in group two. To start with, the top grade (9), which is the first dispersion indicator, is found in the first group only as one student could reach $90 \%$ right answers while no student was able to do so in the second group. Next, the lowest score, which is the second indicator of dispersion, is 02 in group one whereas it is 01 in group two obtained by 2 participants.

Comparison of the means, central tendency and dispersion aspects are in favour of a general indication that the participants in group one have performed better than those in group two which may imply that the study results move in the direction of our hypothesis.

\section{Final Thoughts}

All in all, the global analysis of the findings shows that group one surpassed the other group even if the difference in the mean does not seem great. In fact, findings of the present study lead to some important conclusions concerning the use of cultural elements for assisting students to grasp vocabulary meaning during guessing from context activities. On the one hand, it can be noticed that group one misinterpreted three words: amendment, sustained and accommodated. An examination of both students' answers and the examples in which these words appear may explain why this was the case. For example, in the sentence:

- In 2008, Tamazight became a national language by the constitutional amendment that President Boutaflika had proposed.

'amendment' received $80 \%$ of wrong guesses. Instead of defining it as 'change', students opted for 'decision'. Because the sentence includes 'president Boutaflika', they thought that it was by a President's decision that Tamazight became a national language. Likewise, the word sustained as used in the following example was misunderstood by $70 \%$ of the sample:

- The first person to sustain the prophet Mohammed after his prophethood was his wife 'Khadidja'.

After reading this sentence and relying on their prior knowledge, students justifiably defined sustained as believed. A result which leads us to contend - 
justifiably also- that teachers when building sentences should be very cautious to avoid similar confounding and misleading examples. In the same way, students interpreted accommodated as sheltered since this is the idea construed from its use in:

- During earthquakes Algeria witnessed, victims were accommodated in schools temporarily until they move to new accommodation.

On the other hand, a very high percentage of the participants in group two (98\%) provided a good equivalent for 'consent' which is 'permission':

- You can only come on the trip if your parents give their consent.

A glance at the context makes it clear that the idea expressed here is not alien to the students' own culture (where children cannot go on a trip without their parents' permission); thus, they easily got the right meaning of the word in question. A parallel situation is found in the statement:

- We have concerns about whether the government will be able to provide poorer families with viable social services.

$70 \%$ of group two succeeded in finding the meaning of 'provided...with' (help/offer) because the context is rich enough in clues pertinent to their society as well: government, poorer, social services.

All things considered, and as an answer to the questions addressed in this study, we can safely say that incorporating students' homeland culture in their learning of English as a FL is, in the main, important and useful. Indeed, the more familiar and relevant elements a context includes; the more likely students will succeed to speculate word meaning.

\section{Conclusion}

In summary, the accumulated evidence on the utility of using culture while teaching a foreign language resulted in language teaching syllabi where culture is an integral part. At first, importance was given only to the foreign culture teaching; later on, learners' own culture came into view. Presenting ELLs with new vocabulary is a task in the heart of the foreign language teaching process, and selecting appropriate activities to complete this task is vital. Many researchers suggest to embed target words within a social and cultural context that is relevant and meaningful to learners facilitates their comprehension and assimilation. The findings of this study confirm the pertinence of this view: tapping into students' cultural and social context is of ample help for them to acquire new vocabulary.

\section{References}

1. Alhasiany, F. (2014) English Language Learners. International Journal of Business and Social Science, 5 (8), 38-43.

2. Alptekin, C. (1993) Target-language culture in EFL Materials. ELT Journal, 47(2), 136-143. 
3. Barfield, S.C. ; Uzarski, J. (2009). Integrating Indigenous Cultures into English Language Teaching. English Teaching Forum 12(9).

4. Broemmel, A. D.; Jordan, J.; Whitsett, B. M. (2015) Learning to be Teacher Leaders: A Framework for Assessment, Planning, and Instruction. New York: Routledge

5. Brooks, N. (1968) Teaching Culture in the Foreign Language Classroom. Foreign Language Annals, 1 (3), 204-217.

6. Buttjes, D. (1991) Mediating Languages and Culture: The Social and Intercultural Dimension Restored. In Buttjes, D.; Byram, M. Mediating Languages and Culture: towards an Intercultural Theory of Foreign Language Learning. Clevedon: Multilingual Matters. (eds.). pp 3-16

7. Buttjes, D.; Byram, M. (Eds.). (1991) Mediating Languages and Culture: Towards an Intercultural Theory of Foreign Language Learning. Clevedon: Multilingual Matters.

8. Byram, M. (1994) Culture and Language Learning in Higher Education. Clevedon: Multilingual Matters.

9. Dong, Y. R. (2015) Accelerating Academic Vocabulary. From: http://languagemagazine.com/?page id=4396

10. Eliot, T. S. (1949) Notes towards the Definition of Culture. New York: Harcourt. From:

https://books.google.dz/books/about/Notes_Towards_the_Definition_of_Cultur e.html?id=QYR9FNyKMmwC\&redir_esc=y

11. Klippel, F. (1994) Cultural Aspects in Foreign Language Teaching. Journal for the Study of British Cultures, 1(1), 49-61

12. Kramsh, C. (1998) Language and Culture. Oxford: Oxford University Press.

13. Meyer, M. (1991) Developing Transactional Competence: Case Studies of Advanced Foreign Language Learners. In Buttjes, D.; Byram, M. Mediating Languages and Culture: Towards an Intercultural Theory of Foreign Language Learning. (eds.). (pp 136-158). Clevedon: Multilingual Matters.

14. Nieto, S. (2010) Language, Culture, and Teaching: Critical Perspectives for a New Century ( $2^{\text {nd }}$ ed.). New York: Routledge.

15. Reimann, A. (2009) A critical analysis of cultural content in EFL materials. Utsunomiya University Journal of the Faculty of International Studies, 28(8), 85-101.

16. Risager, K. (2006). Language and Culture: Global Flows and Local Complexity. Clevedon: Multilingual Matters.

17. Sharifian, F. (2015). The Routledge Handbook of Language and Culture. NY: Routledge.

18. Thomas, C. (2014) Meeting EFL Learners Halfway by Using Locally Relevant Authentic Materials. English Teaching Forum, 3, 14-23 
19. Vickov, G. (2007). Learners' Own Cultural Identity in Early EFL. In M. Nikolov, J. M.; Djigunović, M. M.; G. Lundberg, T. Flanagan (Eds.), Teaching Modern Languages to Young Learners: Teachers, Curricula and Materials. (pp 105-120).Graz: European Centre for Modern Languages, Council of Europe.

20. Wardhaugh, R. (2010). An introduction to sociolinguistics (6 $6^{\text {th }}$ ed.). Oxford: Blackwell Publishers Ltd.

21. Woods, E. G. (1994) British Studies in English Language Teaching. In Byram, M. (ed.), Culture and Language Learning in Higher Education. (pp 79-90).Clevedon: Multilingual Matters.

Appendix 1: Test One (relevant to students' own culture and intended to group one)

\section{TEST}

Directions: determine the meaning of the words in boldface using context clues and your prior knowledge.

1. During earthquakes Algeria witnessed, victims were accommodated in schools temporarily until they moved to new accommodation.

accommodated:

2. In 2008, Tamazight became a national language by the constitutional amendment that President A. Boutaflika had proposed.

\section{amendment:}

3. Algeria's most exported commodities include petroleum and natural gas and most imported commodities include food and chemicals.

commodities:

4. According to the Islamic religion, a woman should not be forced into marriage; on the contrary, she can only get married if she gives her consent. consent:

5. The police fined him $2000 \mathrm{DA}$ for not wearing the seatbelt. fined:

6. Education is free in Algerian universities; students must not pay any schooling fees.

fees:

7. The Index is a local TV channel viewed by many people. 
Index:

\begin{tabular}{|c|c|c|c|c|c|c|c|c|c|c|c|c|c|}
\hline & 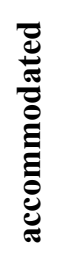 & 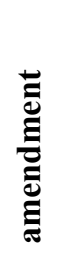 & 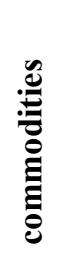 & $\begin{array}{l}\stackrel{\Xi}{0} \\
0 \\
\tilde{\Xi}\end{array}$ & 异 & 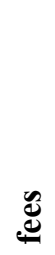 & $\stackrel{\ddot{e}}{\stackrel{\partial}{0}}$ & $\frac{\overrightarrow{0}}{\frac{2}{0}}$ & 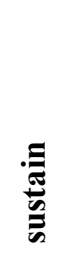 & 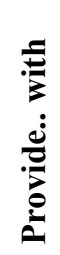 & 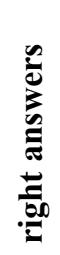 & 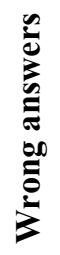 & 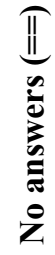 \\
\hline 1 & $\mathrm{n}$ & $===$ & $\mathrm{y}$ & $\mathrm{y}$ & $\mathrm{n}$ & $\mathrm{y}$ & $\mathrm{y}$ & $\mathrm{n}$ & $\mathrm{n}$ & $\mathrm{n}$ & 4 & 5 & 1 \\
\hline 2 & $\mathrm{n}$ & $\mathrm{n}$ & $\mathrm{n}$ & $\mathrm{n}$ & $\mathrm{y}$ & $\mathrm{n}$ & $\mathrm{n}$ & $\mathrm{y}$ & $\mathrm{n}$ & $\mathrm{n}$ & 2 & 8 & \\
\hline 3 & $\mathrm{n}$ & $\mathrm{n}$ & $y$ & $\mathrm{y}$ & $\mathrm{y}$ & $\mathrm{y}$ & $\mathrm{y}$ & $y$ & $\mathrm{n}$ & $y$ & 7 & 3 & \\
\hline 4 & $\mathrm{y}$ & $\mathrm{n}$ & $\mathrm{n}$ & $\mathrm{n}$ & $\mathrm{n}$ & $\mathrm{y}$ & $\mathrm{n}$ & $===$ & $\mathrm{y}$ & $\mathrm{y}$ & 4 & 5 & 1 \\
\hline 5 & $\mathrm{y}$ & $\mathrm{n}$ & $\mathrm{y}$ & $\mathrm{y}$ & $\mathrm{y}$ & $\mathrm{y}$ & $\mathrm{y}$ & $\mathrm{y}$ & $\mathrm{n}$ & $\mathrm{y}$ & 8 & 2 & \\
\hline 6 & $\mathrm{y}$ & $\mathrm{n}$ & $\mathrm{n}$ & $\mathrm{y}$ & $\mathrm{n}$ & $\mathrm{y}$ & $\mathrm{n}$ & $\mathrm{n}$ & $\mathrm{n}$ & $\mathrm{n}$ & 3 & 7 & \\
\hline 7 & $\mathrm{n}$ & $\mathrm{n}$ & $\mathrm{y}$ & $\mathrm{y}$ & $\mathrm{y}$ & $\mathrm{y}$ & $\mathrm{y}$ & $===$ & $\mathrm{n}$ & $\mathrm{y}$ & 6 & 3 & 1 \\
\hline 8 & $\mathrm{y}$ & $\mathrm{n}$ & $\mathrm{y}$ & $\mathrm{n}$ & $\mathrm{y}$ & $\mathrm{y}$ & $\mathrm{y}$ & $===$ & $\mathrm{n}$ & $\mathrm{y}$ & 6 & 3 & 1 \\
\hline 9 & $\mathrm{y}$ & $\mathrm{n}$ & $\mathrm{n}$ & $\mathrm{y}$ & $\mathrm{y}$ & $\mathrm{y}$ & $\mathrm{n}$ & $\mathrm{n}$ & $\mathrm{y}$ & $\mathrm{y}$ & 6 & 4 & \\
\hline 1 & $\mathrm{n}$ & $\mathrm{n}$ & $y$ & $\mathrm{y}$ & $\mathrm{y}$ & $\mathrm{y}$ & $\mathrm{n}$ & $y$ & $\mathrm{y}$ & $\mathrm{y}$ & 7 & 3 & \\
\hline 1 & $\mathrm{n}$ & $\mathrm{n}$ & $\mathrm{y}$ & $\mathrm{y}$ & $\mathrm{n}$ & $\mathrm{y}$ & $\mathrm{n}$ & $\mathrm{n}$ & $\mathrm{y}$ & $\mathrm{y}$ & 5 & 5 & \\
\hline 1 & $\mathrm{y}$ & $\mathrm{n}$ & $\mathrm{y}$ & $\mathrm{y}$ & $\mathrm{y}$ & $\mathrm{y}$ & $\mathrm{y}$ & $\mathrm{n}$ & $\mathrm{n}$ & $\mathrm{y}$ & 7 & 3 & \\
\hline 1 & $\mathrm{n}$ & $\mathrm{n}$ & $\mathrm{y}$ & $\mathrm{y}$ & $\mathrm{y}$ & $\mathrm{y}$ & & $\mathrm{y}$ & $\mathrm{n}$ & $\mathrm{y}$ & 6 & 3 & 1 \\
\hline 1 & $\mathrm{n}$ & $===$ & $\mathrm{n}$ & $\mathrm{y}$ & $\mathrm{n}$ & $\mathrm{y}$ & $\mathrm{n}$ & $\mathrm{n}$ & $\mathrm{n}$ & & 2 & 6 & 1 \\
\hline 1 & $\mathrm{y}$ & $\mathrm{n}$ & $\mathrm{y}$ & $\mathrm{y}$ & $\mathrm{n}$ & $\mathrm{n}$ & $\mathrm{n}$ & $\mathrm{n}$ & $\mathrm{n}$ & $\mathrm{y}$ & 4 & 6 & \\
\hline 1 & $\mathrm{y}$ & $===$ & $===$ & $\mathrm{y}$ & $\mathrm{y}$ & $\mathrm{y}$ & $\mathrm{y}$ & $===$ & $\mathrm{n}$ & $\mathrm{y}$ & 6 & 1 & 3 \\
\hline 1 & $\mathrm{y}$ & $\mathrm{n}$ & $\mathrm{y}$ & $\mathrm{n}$ & $\mathrm{y}$ & $\mathrm{n}$ & $\mathrm{y}$ & $\mathrm{y}$ & $\mathrm{n}$ & $\mathrm{y}$ & 6 & 4 & \\
\hline 1 & $\mathrm{n}$ & $===$ & $===$ & $\mathrm{y}$ & $\mathrm{y}$ & $\mathrm{y}$ & $\mathrm{y}$ & $===$ & $\mathrm{n}$ & $\mathrm{y}$ & 5 & 2 & 3 \\
\hline 1 & $\mathrm{n}$ & $\mathrm{n}$ & $\mathrm{y}$ & $\mathrm{n}$ & $y$ & $y$ & $\mathrm{y}$ & $\mathrm{y}$ & $y$ & $\mathrm{y}$ & 7 & 3 & \\
\hline 2 & $\mathrm{y}$ & $\mathrm{n}$ & $\mathrm{n}$ & $\mathrm{y}$ & $\mathrm{n}$ & $\mathrm{y}$ & $\mathrm{n}$ & $\mathrm{n}$ & $\mathrm{y}$ & $\mathrm{y}$ & 5 & 5 & \\
\hline 2 & $\mathrm{n}$ & $\mathrm{n}$ & $\mathrm{n}$ & $y$ & $\mathrm{y}$ & $\mathrm{y}$ & $\mathrm{y}$ & $\mathrm{y}$ & $\mathrm{n}$ & $\mathrm{y}$ & 6 & 4 & \\
\hline 2 & $\mathrm{y}$ & $\mathrm{n}$ & $===$ & $\mathrm{y}$ & $\mathrm{y}$ & $\mathrm{y}$ & $y$ & $y$ & $\mathrm{n}$ & $\mathrm{n}$ & 6 & 3 & 1 \\
\hline 2 & $\mathrm{n}$ & $\mathrm{n}$ & $\mathrm{y}$ & $\mathrm{y}$ & $\mathrm{n}$ & $\mathrm{y}$ & $\mathrm{y}$ & $\mathrm{y}$ & $\mathrm{n}$ & $\mathrm{y}$ & 6 & 4 & \\
\hline 2 & $\mathrm{y}$ & $\mathrm{n}$ & $\mathrm{y}$ & $\mathrm{n}$ & $\mathrm{y}$ & $\mathrm{y}$ & $\mathrm{n}$ & $\mathrm{y}$ & $\mathrm{n}$ & $\mathrm{y}$ & 6 & 4 & \\
\hline 2 & $\mathrm{y}$ & $\mathrm{n}$ & $\mathrm{y}$ & $\mathrm{y}$ & $\mathrm{n}$ & $\mathrm{y}$ & $\mathrm{y}$ & $\mathrm{n}$ & $\mathrm{n}$ & $\mathrm{y}$ & 6 & 4 & \\
\hline 2 & $\mathrm{n}$ & $\mathrm{n}$ & $\mathrm{y}$ & $\mathrm{n}$ & $\mathrm{n}$ & $\mathrm{y}$ & $y$ & $y$ & $\mathrm{n}$ & $\mathrm{y}$ & 5 & 5 & \\
\hline 2 & $y$ & $\mathrm{n}$ & $y$ & $y$ & $y$ & $\mathrm{n}$ & $\mathrm{n}$ & $\mathrm{n}$ & $\mathrm{n}$ & & 4 & 5 & 1 \\
\hline 2 & $===$ & $\mathrm{n}$ & $\mathrm{n}$ & $\mathrm{y}$ & $\mathrm{n}$ & $\mathrm{y}$ & $\mathrm{y}$ & $\mathrm{y}$ & $\mathrm{n}$ & $\mathrm{y}$ & 5 & 4 & 1 \\
\hline 2 & $\mathrm{n}$ & $===$ & $===$ & $\mathrm{y}$ & $\mathrm{n}$ & $\mathrm{y}$ & $\mathrm{n}$ & $\mathrm{y}$ & $\mathrm{y}$ & $\mathrm{y}$ & 5 & 3 & 2 \\
\hline 3 & $y$ & $\mathrm{n}$ & $\mathrm{y}$ & $y$ & $y$ & $\mathrm{n}$ & $y$ & $\mathrm{n}$ & $y$ & $\mathrm{n}$ & 6 & 4 & \\
\hline 3 & $\mathrm{n}$ & $\mathrm{n}$ & $\mathrm{n}$ & $\mathrm{y}$ & $\mathrm{n}$ & $y$ & $\mathrm{y}$ & $\mathrm{y}$ & $\mathrm{n}$ & $\mathrm{n}$ & 4 & 6 & \\
\hline 3 & $\mathrm{n}$ & $\mathrm{n}$ & $\mathrm{y}$ & $\mathrm{y}$ & $\mathrm{y}$ & $\mathrm{y}$ & $\mathrm{y}$ & $===$ & $\mathrm{n}$ & $\mathrm{y}$ & 6 & 3 & 1 \\
\hline 3 & $\mathrm{n}$ & $\mathrm{n}$ & $\mathrm{n}$ & $\mathrm{n}$ & $\mathrm{y}$ & $\mathrm{y}$ & $\mathrm{y}$ & $\mathrm{n}$ & $\mathrm{n}$ & $\mathrm{y}$ & 4 & 6 & \\
\hline 3 & $\mathrm{n}$ & $\mathrm{n}$ & $\mathrm{n}$ & $\mathrm{y}$ & $\mathrm{y}$ & $\mathrm{y}$ & $\mathrm{n}$ & $\mathrm{n}$ & $\mathrm{n}$ & $\mathrm{y}$ & 4 & 6 & \\
\hline 3 & $\mathrm{n}$ & $\mathrm{n}$ & $\mathrm{y}$ & $\mathrm{n}$ & $\mathrm{n}$ & $\mathrm{y}$ & $\mathrm{n}$ & $\mathrm{n}$ & $\mathrm{n}$ & $\mathrm{y}$ & 3 & 7 & \\
\hline 3 & $\mathrm{n}$ & $\mathrm{n}$ & $\mathrm{y}$ & $\mathrm{n}$ & $\mathrm{n}$ & $\mathrm{y}$ & $\mathrm{y}$ & $\mathrm{y}$ & $\mathrm{y}$ & $\mathrm{y}$ & 6 & 4 & \\
\hline 3 & $\mathrm{n}$ & $\mathrm{y}$ & $y$ & $\mathrm{y}$ & $\mathrm{y}$ & $y$ & $\mathrm{n}$ & $\mathrm{n}$ & $\mathrm{y}$ & $\mathrm{y}$ & 7 & 3 & \\
\hline 3 & $\mathrm{y}$ & $\mathrm{n}$ & $\mathrm{y}$ & & $\mathrm{y}$ & $\mathrm{y}$ & & $\mathrm{n}$ & $\mathrm{n}$ & $\mathrm{y}$ & 5 & 3 & 2 \\
\hline
\end{tabular}


Integrating Students' Own Cultre in the Teaching of Vocabulary

\begin{tabular}{|l|l|l|l|l|l|l|l|l|l|l|l|l|l|}
\hline 3 & $\mathrm{y}$ & $\mathrm{n}$ & $\mathrm{y}$ & $\mathrm{y}$ & $\mathrm{y}$ & $\mathrm{y}$ & $\mathrm{y}$ & $===$ & $\mathrm{n}$ & $\mathrm{y}$ & $\mathbf{7}$ & $\mathbf{2}$ & $\mathbf{1}$ \\
\hline 4 & $\mathrm{n}$ & $\mathrm{n}$ & $\mathrm{y}$ & $\mathrm{y}$ & $\mathrm{y}$ & $\mathrm{y}$ & $\mathrm{n}$ & $\mathrm{n}$ & & $\mathrm{y}$ & $\mathbf{5}$ & $\mathbf{4}$ & $\mathbf{1}$ \\
\hline 4 & $\mathrm{n}$ & $\mathrm{n}$ & $\mathrm{y}$ & $\mathrm{y}$ & $\mathrm{y}$ & $\mathrm{y}$ & & $\mathrm{y}$ & $\mathrm{y}$ & $\mathrm{y}$ & $\mathbf{7}$ & $\mathbf{2}$ & $\mathbf{1}$ \\
\hline 4 & $\mathrm{n}$ & $\mathrm{n}$ & $\mathrm{n}$ & $\mathrm{y}$ & $\mathrm{n}$ & $\mathrm{y}$ & $\mathrm{n}$ & $\mathrm{y}$ & $\mathrm{y}$ & $\mathrm{n}$ & $\mathbf{4}$ & $\mathbf{6}$ & \\
\hline 4 & $\mathrm{n}$ & $===$ & $\mathrm{n}$ & $\mathrm{n}$ & $\mathrm{n}$ & $\mathrm{y}$ & $\mathrm{y}$ & $===$ & $\mathrm{n}$ & $\mathrm{y}$ & $\mathbf{3}$ & $\mathbf{5}$ & $\mathbf{2}$ \\
\hline 4 & $\mathrm{n}$ & $\mathrm{n}$ & $\mathrm{n}$ & $\mathrm{y}$ & $\mathrm{y}$ & $\mathrm{y}$ & $\mathrm{y}$ & $\mathrm{n}$ & $\mathrm{y}$ & $\mathrm{y}$ & $\mathbf{6}$ & $\mathbf{4}$ & \\
\hline 4 & $\mathrm{y}$ & $===$ & $\mathrm{n}$ & $\mathrm{y}$ & $\mathrm{y}$ & $\mathrm{y}$ & $\mathrm{y}$ & $\mathrm{y}$ & $\mathrm{n}$ & $\mathrm{y}$ & $\mathbf{7}$ & $\mathbf{2}$ & $\mathbf{1}$ \\
\hline 4 & $\mathrm{n}$ & $\mathrm{n}$ & $\mathrm{y}$ & $\mathrm{y}$ & $\mathrm{y}$ & $\mathrm{y}$ & $\mathrm{y}$ & $\mathrm{y}$ & $\mathrm{n}$ & $\mathrm{y}$ & $\mathbf{7}$ & $\mathbf{3}$ & \\
\hline 4 & $\mathrm{n}$ & $===$ & $\mathrm{y}$ & $\mathrm{y}$ & $\mathrm{y}$ & $\mathrm{y}$ & $\mathrm{y}$ & $\mathrm{y}$ & $\mathrm{n}$ & $\mathrm{y}$ & $\mathbf{7}$ & $\mathbf{2}$ & $\mathbf{1}$ \\
\hline 4 & $\mathrm{n}$ & $\mathrm{y}$ & $\mathrm{y}$ & $\mathrm{y}$ & $\mathrm{y}$ & $\mathrm{y}$ & $\mathrm{n}$ & $\mathrm{y}$ & $\mathrm{n}$ & $\mathrm{y}$ & $\mathbf{7}$ & $\mathbf{3}$ & \\
\hline 4 & $\mathrm{n}$ & $\mathrm{n}$ & $\mathrm{y}$ & $\mathrm{y}$ & $\mathrm{y}$ & $\mathrm{y}$ & $\mathrm{n}$ & $\mathrm{n}$ & $\mathrm{n}$ & $\mathrm{y}$ & $\mathbf{5}$ & $\mathbf{5}$ & \\
\hline 5 & $\mathrm{y}$ & $\mathrm{n}$ & $\mathrm{y}$ & $\mathrm{y}$ & $\mathrm{y}$ & $\mathrm{y}$ & $\mathrm{y}$ & $\mathrm{y}$ & $\mathrm{y}$ & $\mathrm{y}$ & $\mathbf{9}$ & $\mathbf{1}$ & \\
\hline
\end{tabular}

8. In the social housing system, the Algerian government offers subsidies for middle-income people to help them own a home.

\section{subsidies:}

9. The first person who sustained the prophet Mohammed after his prophethood was his wife 'Khadidja'.

sustain:

10.The National Agency for Employment Support of Youth (ANSEJ) provides Algerian young people with the money necessary for them to start their own businesses.

provide....with:

Appendix 2: Test Two (relevant to the target language culture and intended to group two)

\section{TEST}

Directions: Determine the meaning of the words in boldface using context clues and your prior knowledge.

1. New students may be accommodated in halls of residence.

accommodated :

2. Presidential power was reduced by a constitutional amendment in 1991.

amendment:

3. The country's most valuable commodities include tin and diamonds. commodities:

4. You can only come on the trip if your parents give their consent. 
consent:

5. Drivers who exceed the speed limit can expect to be fined heavily by the police.

fined:

6. The students are holding a demonstation to protest against the increase in their fees.

fees:

7. The heat index is a measure of how hot the air feels. index:

8. They are planning to increase housing subsidies for the poor. subsidies:

9. She was sustained by the strength of her religious faith.

sustained:

10. We have concerns about whether the government will be able to provide poorer families with viable social services.

Provide....with: 


\begin{tabular}{|c|c|c|c|c|c|c|c|c|c|c|c|c|c|}
\hline$\stackrel{\mathscr{E}}{\stackrel{E}{\Xi}}$ & 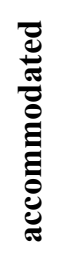 & 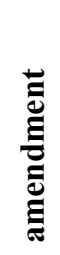 & 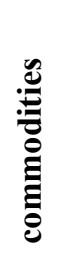 & 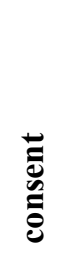 & 苛 & $\underset{\mathscr{E}}{\mathscr{E}}$ & 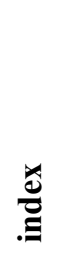 & 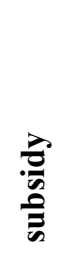 & 离 & 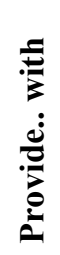 & 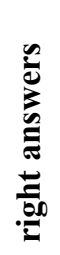 & 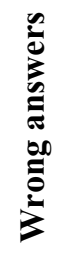 & 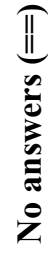 \\
\hline 1 & $\mathrm{n}$ & & $\mathrm{y}$ & $\mathrm{y}$ & $\mathrm{n}$ & $\mathrm{y}$ & $\mathrm{y}$ & $\mathrm{n}$ & $\mathrm{n}$ & $\mathrm{n}$ & 4 & 5 & 1 \\
\hline 2 & $\mathrm{n}$ & $\mathrm{n}$ & $\mathrm{n}$ & $\mathrm{n}$ & $\mathrm{y}$ & $\mathrm{n}$ & $\mathrm{n}$ & $\mathrm{y}$ & $\mathrm{n}$ & $\mathrm{n}$ & 2 & 8 & \\
\hline 3 & $\mathrm{n}$ & $\mathrm{n}$ & $\mathrm{y}$ & $\mathrm{y}$ & $\mathrm{y}$ & $\mathrm{y}$ & $\mathrm{y}$ & $\mathrm{y}$ & $\mathrm{n}$ & $\mathrm{y}$ & 7 & 3 & \\
\hline 4 & $\mathrm{y}$ & $\mathrm{n}$ & $\mathrm{n}$ & $\mathrm{n}$ & $\mathrm{n}$ & $\mathrm{y}$ & $\mathrm{n}$ & & $\mathrm{y}$ & $\mathrm{y}$ & 4 & 5 & 1 \\
\hline 5 & $\mathrm{y}$ & $\mathrm{n}$ & $\mathrm{y}$ & $\mathrm{y}$ & $\mathrm{y}$ & $\mathrm{y}$ & $\mathrm{y}$ & $\mathrm{y}$ & $\mathrm{n}$ & $\mathrm{y}$ & 8 & 2 & \\
\hline 6 & $\mathrm{y}$ & $\mathrm{n}$ & $\mathrm{n}$ & $\mathrm{y}$ & $\mathrm{n}$ & $\mathrm{y}$ & $\mathrm{n}$ & $\mathrm{n}$ & $\mathrm{n}$ & $\mathrm{n}$ & 3 & 7 & \\
\hline 7 & $\mathrm{n}$ & $\mathrm{n}$ & $\mathrm{y}$ & $\mathrm{y}$ & $\mathrm{y}$ & $\mathrm{y}$ & $\mathrm{y}$ & & $\mathrm{n}$ & $\mathrm{y}$ & 6 & 3 & 1 \\
\hline 8 & $\mathrm{y}$ & $\mathrm{n}$ & $\mathrm{y}$ & $\mathrm{n}$ & $\mathrm{y}$ & $\mathrm{y}$ & $\mathrm{y}$ & & $\mathrm{n}$ & $\mathrm{y}$ & 6 & 3 & 1 \\
\hline 9 & $\mathrm{y}$ & $\mathrm{n}$ & $\mathrm{n}$ & $\mathrm{y}$ & $\mathrm{y}$ & $\mathrm{y}$ & $\mathrm{n}$ & $\mathrm{n}$ & $\mathrm{y}$ & $\mathrm{y}$ & 6 & 4 & \\
\hline 10 & $\mathrm{n}$ & $\mathrm{n}$ & $\mathrm{y}$ & $\mathrm{y}$ & $\mathrm{y}$ & $\mathrm{y}$ & $\mathrm{n}$ & $\mathrm{y}$ & $\mathrm{y}$ & $\mathrm{y}$ & 7 & 3 & \\
\hline 11 & $\mathrm{n}$ & $\mathrm{n}$ & $\mathrm{y}$ & $\mathrm{y}$ & $\mathrm{n}$ & $\mathrm{y}$ & $\mathrm{n}$ & $\mathrm{n}$ & $\mathrm{y}$ & $\mathrm{y}$ & 5 & 5 & \\
\hline 12 & $\mathrm{y}$ & $\mathrm{n}$ & $\mathrm{y}$ & $\mathrm{y}$ & $\mathrm{y}$ & $\mathrm{y}$ & $\mathrm{y}$ & $\mathrm{n}$ & $\mathrm{n}$ & $\mathrm{y}$ & 7 & 3 & \\
\hline 13 & $\mathrm{n}$ & $\mathrm{n}$ & $\mathrm{y}$ & $\mathrm{y}$ & $\mathrm{y}$ & $\mathrm{y}$ & & $\mathrm{y}$ & $\mathrm{n}$ & $\mathrm{y}$ & 6 & 3 & 1 \\
\hline 14 & $\mathrm{n}$ & & $\mathrm{n}$ & $\mathrm{y}$ & $\mathrm{n}$ & $\mathrm{y}$ & $\mathrm{n}$ & $\mathrm{n}$ & $\mathrm{n}$ & & 2 & 6 & 1 \\
\hline 15 & $\mathrm{y}$ & $\mathrm{n}$ & $\mathrm{y}$ & $\mathrm{y}$ & $\mathrm{n}$ & $\mathrm{n}$ & $\mathrm{n}$ & $\mathrm{n}$ & $\mathrm{n}$ & $\mathrm{y}$ & 4 & 6 & \\
\hline 16 & $\mathrm{y}$ & & & $\mathrm{y}$ & $\mathrm{y}$ & $\mathrm{y}$ & $\mathrm{y}$ & & $\mathrm{n}$ & $\mathrm{y}$ & 6 & 1 & 3 \\
\hline 17 & $\mathrm{y}$ & $\mathrm{n}$ & $\mathrm{y}$ & $\mathrm{n}$ & $\mathrm{y}$ & $\mathrm{n}$ & $\mathrm{y}$ & $\mathrm{y}$ & $\mathrm{n}$ & $\mathrm{y}$ & 6 & 4 & \\
\hline 18 & $\mathrm{n}$ & & & $\mathrm{y}$ & $\mathrm{y}$ & $\mathrm{y}$ & $\mathrm{y}$ & & $\mathrm{n}$ & $\mathrm{y}$ & 5 & 2 & 3 \\
\hline 19 & $\mathrm{n}$ & $\mathrm{n}$ & $\mathrm{y}$ & $\mathrm{n}$ & $\mathrm{y}$ & $\mathrm{y}$ & $\mathrm{y}$ & $\mathrm{y}$ & $\mathrm{y}$ & $\mathrm{y}$ & 7 & 3 & \\
\hline 20 & $\mathrm{y}$ & $\mathrm{n}$ & $\mathrm{n}$ & $\mathrm{y}$ & $\mathrm{n}$ & $\mathrm{y}$ & $\mathrm{n}$ & $\mathrm{n}$ & $\mathrm{y}$ & $\mathrm{y}$ & 5 & 5 & \\
\hline 21 & $\mathrm{n}$ & $\mathrm{n}$ & $\mathrm{n}$ & $\mathrm{y}$ & $\mathrm{y}$ & $\mathrm{y}$ & $\mathrm{y}$ & $\mathrm{y}$ & $\mathrm{n}$ & $\mathrm{y}$ & 6 & 4 & \\
\hline 22 & $\mathrm{y}$ & $\mathrm{n}$ & & $\mathrm{y}$ & $\mathrm{y}$ & $\mathrm{y}$ & $\mathrm{y}$ & $\mathrm{y}$ & $\mathrm{n}$ & $\mathrm{n}$ & 6 & 3 & 1 \\
\hline 23 & $\mathrm{n}$ & $\mathrm{n}$ & $\mathrm{y}$ & $\mathrm{y}$ & $\mathrm{n}$ & $\mathrm{y}$ & $\mathrm{y}$ & $\mathrm{y}$ & $\mathrm{n}$ & $\mathrm{y}$ & 6 & 4 & \\
\hline 24 & $\mathrm{y}$ & $\mathrm{n}$ & $\mathrm{y}$ & $\mathrm{n}$ & $\mathrm{y}$ & $\mathrm{y}$ & $\mathrm{n}$ & $\mathrm{y}$ & $\mathrm{n}$ & $\mathrm{y}$ & 6 & 4 & \\
\hline 25 & $\mathrm{y}$ & $\mathrm{n}$ & $\mathrm{y}$ & $\mathrm{y}$ & $\mathrm{n}$ & $\mathrm{y}$ & $\mathrm{y}$ & $\mathrm{n}$ & $\mathrm{n}$ & $\mathrm{y}$ & 6 & 4 & \\
\hline 26 & $\mathrm{n}$ & $\mathrm{n}$ & $\mathrm{y}$ & $\mathrm{n}$ & $\mathrm{n}$ & $\mathrm{y}$ & $\mathrm{y}$ & $\mathrm{y}$ & $\mathrm{n}$ & $\mathrm{y}$ & 5 & 5 & \\
\hline 27 & $\mathrm{y}$ & $\mathrm{n}$ & $\mathrm{y}$ & $\mathrm{y}$ & $\mathrm{y}$ & $\mathrm{n}$ & $\mathrm{n}$ & $\mathrm{n}$ & $\mathrm{n}$ & & 4 & 5 & 1 \\
\hline 28 & & $\mathrm{n}$ & $\mathrm{n}$ & $\mathrm{y}$ & $\mathrm{n}$ & $\mathrm{y}$ & $\mathrm{y}$ & $\mathrm{y}$ & $\mathrm{n}$ & $\mathrm{y}$ & 5 & 4 & 1 \\
\hline 29 & $\mathrm{n}$ & & & $\mathrm{y}$ & $\mathrm{n}$ & $\mathrm{y}$ & $\mathrm{n}$ & $\mathrm{y}$ & $\mathrm{y}$ & $\mathrm{y}$ & 5 & 3 & 2 \\
\hline 30 & $\mathrm{y}$ & $\mathrm{n}$ & $\mathrm{y}$ & $\mathrm{y}$ & $\mathrm{y}$ & $\mathrm{n}$ & $\mathrm{y}$ & $\mathrm{n}$ & $\mathrm{y}$ & $\mathrm{n}$ & 6 & 4 & \\
\hline 31 & $\mathrm{n}$ & $\mathrm{n}$ & $\mathrm{n}$ & $\mathrm{y}$ & $\mathrm{n}$ & $\mathrm{y}$ & $\mathrm{y}$ & $\mathrm{y}$ & $\mathrm{n}$ & $\mathrm{n}$ & 4 & 6 & \\
\hline 32 & $\mathrm{n}$ & $\mathrm{n}$ & $\mathrm{y}$ & $\mathrm{y}$ & $\mathrm{y}$ & $\mathrm{y}$ & $\mathrm{y}$ & & $\mathrm{n}$ & $\mathrm{y}$ & 6 & 3 & 1 \\
\hline 33 & $\mathrm{n}$ & $\mathrm{n}$ & $\mathrm{n}$ & $\mathrm{n}$ & $\mathrm{y}$ & $\mathrm{y}$ & $\mathrm{y}$ & $\mathrm{n}$ & $\mathrm{n}$ & $\mathrm{y}$ & 4 & 6 & \\
\hline 34 & $\mathrm{n}$ & $\mathrm{n}$ & $\mathrm{n}$ & $\mathrm{y}$ & $\mathrm{y}$ & $\mathrm{y}$ & $\mathrm{n}$ & $\mathrm{n}$ & $\mathrm{n}$ & $\mathrm{y}$ & 4 & 6 & \\
\hline 35 & $\mathrm{n}$ & $\mathrm{n}$ & $\mathrm{y}$ & $\mathrm{n}$ & $\mathrm{n}$ & $\mathrm{y}$ & $\mathrm{n}$ & $\mathrm{n}$ & $\mathrm{n}$ & $\mathrm{y}$ & 3 & 7 & \\
\hline 36 & $\mathrm{n}$ & $\mathrm{n}$ & $\mathrm{y}$ & $\mathrm{n}$ & $\mathrm{n}$ & $\mathrm{y}$ & $\mathrm{y}$ & $\mathrm{y}$ & $\mathrm{y}$ & $\mathrm{y}$ & 6 & 4 & \\
\hline 37 & $\mathrm{n}$ & $\mathrm{y}$ & $\mathrm{y}$ & $\mathrm{y}$ & $\mathrm{y}$ & $\mathrm{y}$ & $\mathrm{n}$ & $\mathrm{n}$ & $\mathrm{y}$ & $\mathrm{y}$ & 7 & 3 & \\
\hline 38 & $\mathrm{y}$ & $\mathrm{n}$ & $\mathrm{y}$ & & $\mathrm{y}$ & $\mathrm{y}$ & & $\mathrm{n}$ & $\mathrm{n}$ & $\mathrm{y}$ & 5 & 3 & 2 \\
\hline 39 & $\mathrm{y}$ & $\mathrm{n}$ & $\mathrm{y}$ & $\mathrm{y}$ & $\mathrm{y}$ & $\mathrm{y}$ & $\mathrm{y}$ & & $\mathrm{n}$ & $\mathrm{y}$ & 7 & 2 & 1 \\
\hline 40 & $\mathrm{n}$ & $\mathrm{n}$ & $\mathrm{y}$ & $\mathrm{y}$ & $\mathrm{y}$ & $\mathrm{y}$ & $\mathrm{n}$ & $\mathrm{n}$ & & $\mathrm{y}$ & 5 & 4 & 1 \\
\hline 41 & $\mathrm{n}$ & $\mathrm{n}$ & $\mathrm{y}$ & $\mathrm{y}$ & $\mathrm{y}$ & $\mathrm{y}$ & & $\mathrm{y}$ & $\mathrm{y}$ & $\mathrm{y}$ & 7 & 2 & 1 \\
\hline
\end{tabular}




\begin{tabular}{|l|l|l|l|l|l|l|l|l|l|l|l|l|l|}
\hline 42 & $\mathrm{n}$ & $\mathrm{n}$ & $\mathrm{n}$ & $\mathrm{y}$ & $\mathrm{n}$ & $\mathrm{y}$ & $\mathrm{n}$ & $\mathrm{y}$ & $\mathrm{y}$ & $\mathrm{n}$ & $\mathbf{4}$ & $\mathbf{6}$ & \\
\hline 43 & $\mathrm{n}$ & & $\mathrm{n}$ & $\mathrm{n}$ & $\mathrm{n}$ & $\mathrm{y}$ & $\mathrm{y}$ & & $\mathrm{n}$ & $\mathrm{y}$ & $\mathbf{3}$ & $\mathbf{5}$ & $\mathbf{2}$ \\
\hline 44 & $\mathrm{n}$ & $\mathrm{n}$ & $\mathrm{n}$ & $\mathrm{y}$ & $\mathrm{y}$ & $\mathrm{y}$ & $\mathrm{y}$ & $\mathrm{n}$ & $\mathrm{y}$ & $\mathrm{y}$ & $\mathbf{6}$ & $\mathbf{4}$ & \\
\hline 45 & $\mathrm{y}$ & & $\mathrm{n}$ & $\mathrm{y}$ & $\mathrm{y}$ & $\mathrm{y}$ & $\mathrm{y}$ & $\mathrm{y}$ & $\mathrm{n}$ & $\mathrm{y}$ & $\mathbf{7}$ & $\mathbf{2}$ & $\mathbf{1}$ \\
\hline 46 & $\mathrm{n}$ & $\mathrm{n}$ & $\mathrm{y}$ & $\mathrm{y}$ & $\mathrm{y}$ & $\mathrm{y}$ & $\mathrm{y}$ & $\mathrm{y}$ & $\mathrm{n}$ & $\mathrm{y}$ & $\mathbf{7}$ & $\mathbf{3}$ & \\
\hline 47 & $\mathrm{n}$ & & $\mathrm{y}$ & $\mathrm{y}$ & $\mathrm{y}$ & $\mathrm{y}$ & $\mathrm{y}$ & $\mathrm{y}$ & $\mathrm{n}$ & $\mathrm{y}$ & $\mathbf{7}$ & $\mathbf{2}$ & $\mathbf{1}$ \\
\hline 48 & $\mathrm{n}$ & $\mathrm{y}$ & $\mathrm{y}$ & $\mathrm{y}$ & $\mathrm{y}$ & $\mathrm{y}$ & $\mathrm{n}$ & $\mathrm{y}$ & $\mathrm{n}$ & $\mathrm{y}$ & $\mathbf{7}$ & $\mathbf{3}$ & \\
\hline 49 & $\mathrm{n}$ & $\mathrm{n}$ & $\mathrm{y}$ & $\mathrm{y}$ & $\mathrm{y}$ & $\mathrm{y}$ & $\mathrm{n}$ & $\mathrm{n}$ & $\mathrm{n}$ & $\mathrm{y}$ & $\mathbf{5}$ & $\mathbf{5}$ & \\
\hline 50 & $\mathrm{y}$ & $\mathrm{n}$ & $\mathrm{y}$ & $\mathrm{y}$ & $\mathrm{y}$ & $\mathrm{y}$ & $\mathrm{y}$ & $\mathrm{y}$ & $\mathrm{y}$ & $\mathrm{y}$ & $\mathbf{9}$ & $\mathbf{1}$ & \\
\hline
\end{tabular}

Appendix 3: Students' Individual Answers in Group One

Appendix 4: Students' Individual Answers in Group Two

\begin{tabular}{|c|c|c|c|c|c|c|c|c|c|c|c|c|c|}
\hline$\stackrel{\mathscr{E}}{.:}$ & 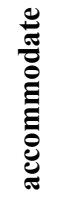 & 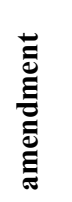 & $\begin{array}{l}\stackrel{\mathscr{E}}{:} \\
: \\
\stackrel{\Xi}{\Xi} \\
:\end{array}$ & 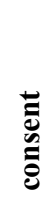 & 悥 & 巳 & $\stackrel{\vec{d}}{.}$ & 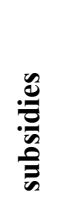 & 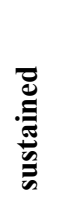 & 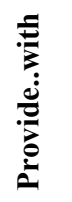 & $\stackrel{0}{\nu}$ & $\ddot{z}$ & 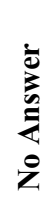 \\
\hline 1 & $\mathrm{n}$ & $\mathrm{y}$ & $\mathrm{n}$ & $\mathrm{y}$ & $\mathrm{n}$ & $\mathrm{y}$ & $\mathrm{y}$ & $\mathrm{n}$ & $\mathrm{n}$ & $\mathrm{y}$ & 5 & 5 & \\
\hline 2 & $\mathrm{n}$ & $\mathrm{n}$ & $\mathrm{n}$ & $\mathrm{y}$ & $\mathrm{y}$ & $\mathrm{y}$ & $\mathrm{y}$ & $\mathrm{n}$ & $\mathrm{n}$ & $\mathrm{y}$ & 5 & 5 & \\
\hline 3 & $===$ & $===$ & $\mathrm{n}$ & $\mathrm{y}$ & $\mathrm{n}$ & $\mathrm{n}$ & $\mathrm{y}$ & $===$ & $\mathrm{n}$ & $\mathrm{y}$ & 3 & 4 & 3 \\
\hline 4 & $\mathrm{n}$ & $\mathrm{n}$ & $\mathrm{n}$ & $\mathrm{y}$ & $\mathrm{n}$ & $\mathrm{y}$ & $\mathrm{y}$ & $\mathrm{n}$ & $\mathrm{n}$ & $\mathrm{n}$ & 3 & 7 & \\
\hline 5 & $===$ & $\mathrm{n}$ & $\mathrm{n}$ & $\mathrm{y}$ & $\mathrm{n}$ & $\mathrm{n}$ & $\mathrm{y}$ & $===$ & $\mathrm{n}$ & $\mathrm{n}$ & 2 & 6 & 2 \\
\hline 6 & $\mathrm{n}$ & $\mathrm{n}$ & $\mathrm{y}$ & $\mathrm{y}$ & $\mathrm{y}$ & $\mathrm{n}$ & $===$ & $\mathrm{y}$ & $\mathrm{n}$ & $\mathrm{n}$ & 4 & 5 & 1 \\
\hline 7 & $\mathrm{y}$ & $===$ & $===$ & $\mathrm{y}$ & $\mathrm{n}$ & $\mathrm{n}$ & $\mathrm{y}$ & $===$ & $\mathrm{n}$ & $\mathrm{y}$ & 4 & 3 & 3 \\
\hline 8 & $===$ & $\mathrm{n}$ & $\mathrm{n}$ & $\mathrm{y}$ & $\mathrm{n}$ & $y$ & $\mathrm{y}$ & $\mathrm{y}$ & $\mathrm{n}$ & $\mathrm{y}$ & 5 & 4 & 1 \\
\hline 9 & $==$ & $\mathrm{n}$ & $\mathrm{n}$ & $\mathrm{y}$ & $\mathrm{n}$ & $\mathrm{y}$ & $\mathrm{y}$ & $\mathrm{n}$ & $\mathrm{n}$ & $\mathrm{y}$ & 4 & 5 & 1 \\
\hline 10 & $\mathrm{n}$ & $\mathrm{n}$ & $\mathrm{n}$ & $\mathrm{y}$ & $\mathrm{n}$ & $\mathrm{n}$ & $\mathrm{y}$ & $\mathrm{n}$ & $\mathrm{n}$ & $\mathrm{y}$ & 3 & 7 & \\
\hline 11 & $\mathrm{n}$ & $\mathrm{n}$ & $\mathrm{y}$ & $\mathrm{y}$ & $\mathrm{n}$ & $\mathrm{y}$ & $===$ & $\mathrm{y}$ & $\mathrm{y}$ & $\mathrm{y}$ & 6 & 3 & 1 \\
\hline 12 & $\mathrm{n}$ & $===$ & $\mathrm{y}$ & $\mathrm{y}$ & $\mathrm{n}$ & $\mathrm{y}$ & $===$ & $\mathrm{y}$ & $\mathrm{y}$ & $\mathrm{y}$ & 6 & 2 & 2 \\
\hline 13 & $\mathrm{n}$ & $\mathrm{y}$ & $===$ & $\mathrm{y}$ & $\mathrm{n}$ & $\mathrm{y}$ & $\mathrm{y}$ & $\mathrm{n}$ & $\mathrm{n}$ & $\mathrm{y}$ & 5 & 4 & 1 \\
\hline 14 & $\mathrm{y}$ & $\mathrm{n}$ & $\mathrm{n}$ & $\mathrm{y}$ & $\mathrm{n}$ & $\mathrm{n}$ & $\mathrm{y}$ & $\mathrm{n}$ & $\mathrm{n}$ & $\mathrm{y}$ & 4 & 5 & 1 \\
\hline 15 & $===$ & $\mathrm{n}$ & $===$ & $\mathrm{y}$ & $\mathrm{n}$ & $\mathrm{y}$ & $\mathrm{y}$ & $\mathrm{n}$ & $y$ & $\mathrm{y}$ & 5 & 3 & 2 \\
\hline 16 & $\mathrm{n}$ & $\mathrm{n}$ & $\mathrm{y}$ & $\mathrm{y}$ & $\mathrm{n}$ & $\mathrm{n}$ & $\mathrm{y}$ & $\mathrm{n}$ & $\mathrm{n}$ & $\mathrm{y}$ & 4 & 6 & \\
\hline 17 & $\mathrm{n}$ & $\mathrm{n}$ & $\mathrm{y}$ & $\mathrm{y}$ & $\mathrm{n}$ & $\mathrm{y}$ & $===$ & $\mathrm{n}$ & $y$ & $\mathrm{y}$ & 5 & 4 & 1 \\
\hline 18 & $\mathrm{n}$ & $\mathrm{n}$ & $\mathrm{n}$ & $\mathrm{y}$ & $\mathrm{n}$ & $\mathrm{y}$ & $===$ & $\mathrm{n}$ & $\mathrm{n}$ & $\mathrm{y}$ & 3 & 6 & 1 \\
\hline 19 & $\mathrm{n}$ & $\mathrm{n}$ & $\mathrm{y}$ & $\mathrm{n}$ & $\mathrm{n}$ & $\mathrm{n}$ & $\mathrm{n}$ & $\mathrm{y}$ & $\mathrm{n}$ & $\mathrm{n}$ & 2 & 8 & \\
\hline 20 & $===$ & $\mathrm{n}$ & $\mathrm{n}$ & $y$ & $\mathrm{n}$ & $y$ & $\mathrm{y}$ & $\mathrm{n}$ & $\mathrm{n}$ & $y$ & 4 & 5 & 1 \\
\hline 21 & $\mathrm{n}$ & $\mathrm{n}$ & $\mathrm{n}$ & $\mathrm{y}$ & $\mathrm{n}$ & $\mathrm{n}$ & $===$ & $\mathrm{n}$ & $\mathrm{n}$ & $\mathrm{n}$ & 1 & 8 & 1 \\
\hline 22 & $===$ & $\mathrm{n}$ & $\mathrm{n}$ & $\mathrm{y}$ & $\mathrm{n}$ & $\mathrm{n}$ & $\mathrm{n}$ & $\mathrm{n}$ & $\mathrm{n}$ & $\mathrm{y}$ & 2 & 7 & 1 \\
\hline 23 & $\mathrm{n}$ & $\mathrm{n}$ & $\mathrm{n}$ & $\mathrm{y}$ & $\mathrm{y}$ & $\mathrm{n}$ & $\mathrm{n}$ & $\mathrm{y}$ & $\mathrm{n}$ & $\mathrm{n}$ & 3 & 7 & \\
\hline 24 & $===$ & $\mathrm{y}$ & $\mathrm{n}$ & $\mathrm{y}$ & $\mathrm{Y}$ & $\mathrm{n}$ & $\mathrm{n}$ & $\mathrm{y}$ & $\mathrm{n}$ & $\mathrm{y}$ & 5 & 4 & 1 \\
\hline 25 & $\mathrm{y}$ & $\mathrm{n}$ & $\mathrm{n}$ & $\mathrm{y}$ & $\mathrm{y}$ & $\mathrm{y}$ & $\mathrm{y}$ & $\mathrm{n}$ & $\mathrm{n}$ & $\mathrm{y}$ & 6 & 4 & \\
\hline 26 & $\mathrm{y}$ & $\mathrm{y}$ & $\mathrm{n}$ & $\mathrm{y}$ & $\mathrm{y}$ & $\mathrm{y}$ & $\mathrm{y}$ & $\mathrm{n}$ & $\mathrm{n}$ & $\mathrm{y}$ & 7 & 3 & \\
\hline 27 & $\mathrm{y}$ & $\mathrm{y}$ & $\mathrm{n}$ & $\mathrm{y}$ & $\mathrm{n}$ & $\mathrm{n}$ & $\mathrm{y}$ & $\mathrm{n}$ & $\mathrm{n}$ & $\mathrm{y}$ & 5 & 5 & \\
\hline 28 & $\mathrm{y}$ & $\mathrm{y}$ & $y$ & $\mathrm{y}$ & $\mathrm{n}$ & $==$ & $\mathrm{y}$ & $\mathrm{n}$ & $===$ & $\mathrm{n}$ & 5 & 3 & 2 \\
\hline 29 & $===$ & $===$ & $\mathrm{y}$ & $\mathrm{y}$ & $\mathrm{n}$ & $\mathrm{n}$ & $\mathrm{y}$ & $\mathrm{n}$ & $\mathrm{n}$ & $\mathrm{y}$ & 4 & 4 & 2 \\
\hline 30 & $\mathrm{n}$ & $\mathrm{n}$ & $\mathrm{y}$ & $\mathrm{y}$ & $\mathrm{y}$ & $\mathrm{n}$ & $\mathrm{y}$ & $\mathrm{n}$ & $\mathrm{n}$ & $===$ & 4 & 5 & 1 \\
\hline
\end{tabular}


Integrating Students' Own Cultre in the Teaching of Vocabulary

\begin{tabular}{|l|l|l|l|l|l|l|l|l|l|l|l|l|l|}
\hline 31 & $==$ & $\mathrm{n}$ & $\mathrm{y}$ & $\mathrm{y}$ & $\mathrm{n}$ & $\mathrm{y}$ & $\mathrm{n}$ & $\mathrm{y}$ & $\mathrm{y}$ & $\mathrm{y}$ & $\mathbf{6}$ & $\mathbf{3}$ & $\mathbf{1}$ \\
\hline 32 & $\mathrm{n}$ & $\mathrm{y}$ & $\mathrm{y}$ & $\mathrm{y}$ & $\mathrm{n}$ & $\mathrm{n}$ & $\mathrm{n}$ & $\mathrm{n}$ & $\mathrm{y}$ & $\mathrm{y}$ & $\mathbf{5}$ & $\mathbf{5}$ & \\
\hline 33 & $\mathrm{n}$ & $\mathrm{n}$ & $\mathrm{y}$ & $\mathrm{y}$ & $\mathrm{y}$ & $\mathrm{n}$ & $\mathrm{n}$ & $==$ & $\mathrm{n}$ & $\mathrm{n}$ & $\mathbf{3}$ & $\mathbf{6}$ & $\mathbf{1}$ \\
\hline 34 & $===$ & $\mathrm{n}$ & $\mathrm{n}$ & $\mathrm{y}$ & $\mathrm{n}$ & $==$ & $===$ & $\mathrm{n}$ & $==$ & $===$ & $\mathbf{1}$ & $\mathbf{4}$ & $\mathbf{5}$ \\
\hline 35 & $\mathrm{n}$ & $===$ & $\mathrm{y}$ & $\mathrm{y}$ & $\mathrm{y}$ & $\mathrm{n}$ & $\mathrm{n}$ & $\mathrm{n}$ & $\mathrm{y}$ & $\mathrm{n}$ & $\mathbf{4}$ & $\mathbf{5}$ & $\mathbf{1}$ \\
\hline 36 & $\mathrm{n}$ & $\mathrm{n}$ & $\mathrm{n}$ & $\mathrm{y}$ & $\mathrm{n}$ & $\mathrm{n}$ & $\mathrm{y}$ & $\mathrm{n}$ & $\mathrm{n}$ & $\mathrm{y}$ & $\mathbf{3}$ & $\mathbf{7}$ & \\
\hline 37 & $\mathrm{n}$ & $\mathrm{y}$ & $\mathrm{n}$ & $\mathrm{y}$ & $\mathrm{n}$ & $\mathrm{n}$ & $\mathrm{y}$ & $\mathrm{n}$ & $\mathrm{n}$ & $\mathrm{y}$ & $\mathbf{4}$ & $\mathbf{6}$ & \\
\hline 38 & $\mathrm{n}$ & $\mathrm{y}$ & $\mathrm{y}$ & $\mathrm{y}$ & $\mathrm{n}$ & $\mathrm{n}$ & $\mathrm{y}$ & $\mathrm{n}$ & $\mathrm{y}$ & $\mathrm{y}$ & $\mathbf{6}$ & $\mathbf{4}$ & \\
\hline 39 & $\mathrm{n}$ & $\mathrm{n}$ & $\mathrm{y}$ & $\mathrm{y}$ & $\mathrm{n}$ & $==$ & $===$ & $\mathrm{n}$ & $==$ & $\mathrm{y}$ & $\mathbf{3}$ & $\mathbf{4}$ & $\mathbf{3}$ \\
\hline 40 & $\mathrm{n}$ & $===$ & $\mathrm{y}$ & $\mathrm{y}$ & $\mathrm{n}$ & $==$ & $\mathrm{y}$ & $\mathrm{n}$ & $===$ & $\mathrm{y}$ & $\mathbf{4}$ & $\mathbf{3}$ & $\mathbf{3}$ \\
\hline 41 & $===$ & $===$ & $\mathrm{n}$ & $\mathrm{y}$ & $\mathrm{y}$ & $\mathrm{n}$ & $\mathrm{n}$ & $\mathrm{n}$ & $\mathrm{n}$ & $\mathrm{y}$ & $\mathbf{3}$ & $\mathbf{5}$ & $\mathbf{2}$ \\
\hline 42 & $\mathrm{y}$ & $\mathrm{n}$ & $\mathrm{y}$ & $\mathrm{y}$ & $\mathrm{n}$ & $\mathrm{n}$ & $\mathrm{n}$ & $\mathrm{y}$ & $\mathrm{n}$ & $\mathrm{y}$ & $\mathbf{5}$ & $\mathbf{5}$ & \\
\hline 43 & $===$ & $\mathrm{n}$ & $\mathrm{n}$ & $\mathrm{y}$ & $\mathrm{n}$ & $\mathrm{n}$ & $\mathrm{y}$ & $\mathrm{y}$ & $\mathrm{n}$ & $\mathrm{y}$ & $\mathbf{4}$ & $\mathbf{5}$ & $\mathbf{1}$ \\
\hline 44 & $===$ & $===$ & $\mathrm{y}$ & $\mathrm{y}$ & $\mathrm{n}$ & $\mathrm{y}$ & $\mathrm{y}$ & $===$ & $\mathrm{n}$ & $\mathrm{y}$ & $\mathbf{5}$ & $\mathbf{2}$ & $\mathbf{3}$ \\
\hline 45 & $\mathrm{n}$ & $\mathrm{n}$ & $\mathrm{y}$ & $\mathrm{y}$ & $\mathrm{n}$ & $\mathrm{n}$ & $===$ & $\mathrm{n}$ & $\mathrm{y}$ & $\mathrm{y}$ & $\mathbf{4}$ & $\mathbf{4}$ & $\mathbf{1}$ \\
\hline 46 & $\mathrm{n}$ & $\mathrm{n}$ & $\mathrm{n}$ & $\mathrm{y}$ & $\mathrm{n}$ & $\mathrm{n}$ & $\mathrm{y}$ & $\mathrm{n}$ & $\mathrm{n}$ & $\mathrm{n}$ & $\mathbf{2}$ & $\mathbf{8}$ & \\
\hline 47 & $===$ & $\mathrm{n}$ & $\mathrm{y}$ & $\mathrm{y}$ & $\mathrm{n}$ & $\mathrm{y}$ & $\mathrm{y}$ & $\mathrm{y}$ & $\mathrm{n}$ & $\mathrm{y}$ & $\mathbf{6}$ & $\mathbf{3}$ & $\mathbf{1}$ \\
\hline 48 & $\mathrm{y}$ & $\mathrm{n}$ & $\mathrm{y}$ & $\mathrm{y}$ & $\mathrm{n}$ & $\mathrm{n}$ & $\mathrm{n}$ & $\mathrm{y}$ & $\mathrm{n}$ & $\mathrm{n}$ & $\mathbf{4}$ & $\mathbf{6}$ & \\
\hline 49 & $\mathrm{n}$ & $\mathrm{y}$ & $\mathrm{y}$ & $\mathrm{y}$ & $\mathrm{y}$ & $\mathrm{y}$ & $\mathrm{y}$ & $\mathrm{n}$ & $\mathrm{y}$ & $\mathrm{Y}$ & $\mathbf{8}$ & $\mathbf{2}$ & \\
\hline 50 & $\mathrm{n}$ & $\mathrm{n}$ & $\mathrm{y}$ & $\mathrm{y}$ & $\mathrm{n}$ & $\mathrm{y}$ & $\mathrm{n}$ & $\mathrm{n}$ & $\mathrm{y}$ & $\mathrm{y}$ & $\mathbf{5}$ & $\mathbf{5}$ & \\
\hline
\end{tabular}

\begin{tabular}{|l|c|c|c|c|c|c|}
\hline \multirow{2}{*}{ Items } & \multicolumn{2}{|c|}{ Right answers } & \multicolumn{2}{c|}{ Wrong } & \multicolumn{2}{c|}{ No answers } \\
\cline { 2 - 7 } & $\mathrm{N}^{\circ}$ & $\%$ & $\mathrm{~N}^{\circ}$ & $\%$ & $\mathrm{~N}^{\circ}$ & $\%$ \\
\hline accommodated & 19 & 38 & 30 & 60 & 01 & 2 \\
\hline amendment & 2 & 4 & 40 & 80 & 08 & 16 \\
\hline commodities & 31 & 62 & 15 & 30 & 05 & 10 \\
\hline consent & 38 & 76 & 11 & 22 & 01 & 2 \\
\hline fined & 33 & 66 & 17 & 34 & 00 & 0 \\
\hline fees & 45 & 90 & 05 & 10 & 00 & 0 \\
\hline index & 28 & 56 & 19 & 38 & 03 & 6 \\
\hline subsidies & 23 & 46 & 19 & 38 & 08 & 16 \\
\hline sustained & 14 & 28 & 35 & 70 & 01 & 2 \\
\hline provide...with & 41 & 82 & 07 & 14 & 02 & 4 \\
\hline
\end{tabular}

